\title{
Understanding the Chemistry and Sources of Precipitation Ions in the mid-Brahmaputra Valley of Northeastern India
}

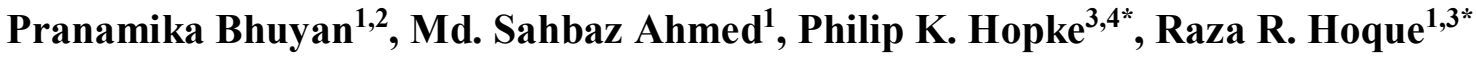 \\ ${ }^{1}$ Department of Environmental Science, Tezpur University, Tezpur 784028, India \\ ${ }^{2}$ Department of Environmental Studies, Assam Women's University, Jorhat 785004, India \\ ${ }^{3}$ Department of Public Health Sciences, University of Rochester Medical Center, Rochester, NY 14642, USA \\ ${ }^{4}$ Center for Air Resources Engineering and Science, Clarkson University, Potsdam, NY 13699, USA
}

\begin{abstract}
The chemistry of rainwater over mid-Brahmaputra Valley was studied for three consecutive years $(2012-2014 ; \mathrm{n}=285)$. The samples were analyzed for major chemical parameters viz. $\mathrm{pH}$, electrical conductivity (EC), and ions $\left(\mathrm{SO}_{4}{ }^{2-}, \mathrm{NO}_{3}{ }^{-}, \mathrm{Cl}^{-}\right.$, $\mathrm{F}^{-}, \mathrm{Br}^{-}, \mathrm{Ca}^{2+}, \mathrm{NH}_{4}^{+}, \mathrm{Mg}^{2+}, \mathrm{Na}^{+}, \mathrm{K}^{+}$, and $\left.\mathrm{Li}^{+}\right)$, organic acids $\left(\mathrm{HCOO}^{-}\right.$and $\mathrm{CH}_{3} \mathrm{COO}^{-}$) and dissolved organic carbon (DOC). The mean $\mathrm{pH}$ for the entire study period was found to be 5.66, which ranged from 4.51 to 7.68 , and the volume weighted (VW) mean $\mathrm{pH}$ was found to be 5.16 . Over $55 \%$ of the samples showed $\mathrm{pH}$ between 5 and 6 , and a few samples had $\mathrm{pH}<5$. Ionic concentration followed the order $\mathrm{NH}_{4}^{+}>\mathrm{Ca}^{2+}>\mathrm{SO}_{4}{ }^{2-}>\mathrm{NO}_{3}^{-}>\mathrm{Cl}^{-}>\mathrm{Na}^{+}>\mathrm{K}^{+}>\mathrm{Mg}^{2+}>\mathrm{H}^{+}>\mathrm{HCO}_{3}^{-}>\mathrm{Br}^{-}>\mathrm{F}^{-}>$ $\mathrm{Li}^{+}$, indicating dominance of alkaline ions over acidic ions such that $94 \%$ of mineral acid was neutralized. The secondary ions, $\mathrm{NH}_{4}{ }^{+}, \mathrm{SO}_{4}{ }^{2-}$, and $\mathrm{NO}_{3}{ }^{-}$, showed high wet deposition fluxes. The chemistry exhibits explicit seasonality. The airmass clusters of monsoon and non-monsoon seasons, and the associated chemistry varied, which showed influence of long-range transport. The interspecies correlations varied between the monsoon and non-monsoon time samples meaning variation in the source strengths of the contribution sources of the chemical species of the rainwater. Positive Matrix Factorization (PMF) was applied to the data which extracted six factors that explained the sources and chemistry of the rainwater constituents which are of sea, agriculture, coal burning, biomass burning, and secondary origin.
\end{abstract}

Keywords: Rainwater chemistry; Source apportionment; HYSPLIT Back trajectory; PMF.

\section{INTRODUCTION}

For many decades, rainwater chemistry has drawn significant attention because of its acidity and the associated consequences on ecosystems. Researchers from various parts of the world have extensively studied rainwater chemistry to gain understanding of this issue (Eriksson, 1952; Likens et al., 1976; Charlson and Rodhe, 1982; Galloway et al., 1982; Zeng and Hopke, 1989; Galloway, 1995; Lacaux et al., 2009; Akpo et al., 2015; Mimura et al., 2016 and references therein). The chemistry of rainwater remains important because of its ecological impacts on biogeochemical cycling of nutrients and climate.

Water-soluble gases and particles present in the atmosphere combine with rainwater through the processes of cloud condensation and/or below cloud scavenging. They are then deposited on the earth's surface. These chemical

\footnotetext{
* Corresponding authors.

E-mail address: phopke@clarkson.edu (P.K. Hopke); rrh@tezu.ernet.in (R.R. Hoque)
}

constituents come from both natural and anthropogenic sources (Rastogi and Sarin, 2005; Mimura et al., 2016). Thus, rainwater chemistry of a region can be considered as an indicator of prevalent atmospheric conditions where the rainwater samples were collected (Al-Khasman, 2005, 2009). The presence of dissolved ions also provides information on both local and long-range transported pollutants (e.g., Tiwari et al., 2007; Chate et al., 2011; Niu et al., 2014; Akpo et al., 2015), and quantitative assessment of wet deposition enables identification of the various natural and anthropogenic source strengths, and their temporal and spatial variabilities (Tiwari et al., 2015).

In India, studies of rainwater chemistry have been performed in different ecological and physical environments (e.g., Rao et al., 1992; Granat et al., 2001; Kulshrestha et al., 2003; Safai et al., 2004; Kulshrestha et al., 2005b; Momin et al., 2005; Mouli et al., 2005; Rastogi and Sarin, 2007; Tiwari et al., 2007; Salve et al., 2008; Budhavant et al., 2009, 2011; Das et al., 2011; Tiwari et al., 2015; Rao et al., 2016). Many studies in India have commonly reported alkaline rainwater in multiple locations (e.g., Handa et al., 1969; Khemani et al., 1985; Rastogi and Sarin, 2005; Kumar et al., 2002; Parashar et al., 2001) due to dominance of neutralizing compounds 
like calcium carbonate and ammonia in the atmosphere (Norman et al., 2001). However, there has been a lack of systematic, long-term studies of rainwater chemistry over the Brahmaputra Valley with only a couple of studies being reported (Kulshrestha et al., 2005a, 2014).

The Brahmaputra Valley is one of the most fertile valleys in the world and is rich with biodiversity. The Valley has been experiencing rapid growth in recent years like many other regions of India. Consequentially, significant heterogeneity has been observed in terms of physical, chemical, and optical properties of the particulate matter across this region as reported by Deka and Hoque (2014a, b), Pathak et al. (2012), and Bhuyan et al. (2016a). Therefore, there is a need to better understand the chemistry of rainwater over the Brahmaputra Valley, through systematic measurements and to assess the effects of atmospheric deposition chemistry in this ecologically fragile region. This paper provides the initial source characterization and apportionment of the rainwater constituents in this region.

\section{EXPERIMENTAL}

\section{The Site}

This work was conducted at Tezpur $\left(26^{\circ} 38^{\prime} \mathrm{N} 92^{\circ} 48^{\prime} \mathrm{E}\right.$ and $\left.26^{\circ} 63^{\prime} \mathrm{N} 92^{\circ} 8^{\prime} \mathrm{E}\right)$, of the mid-Brahmaputra Valley of northeastern India. The airmass back-trajectory clusters, of the monsoon and non-monsoon periods, reaching the site (Tezpur) during the study period are shown in Fig. 1. The climate is sub-tropical with mild winters and hot-and-humid summers and maximum rainfall is received during the monsoon season.

Bhuyan et al. (2016) has described the population and land use type of Tezpur. The region does not have any heavy industries, however, there are some small-scale industries like tea-processing, petroleum refining, cement manufacturing, and mining of minor minerals. The region being mostly rural, the village folks majorly dependent on solid biomass fuels to meet the daily energy needs. Forest fires and agricultural biomass burning are observed during the months preceding the monsoon. Agricultural biomass burning and forest fires are seen during the pre-monsoon season.

Bhuyan et al. (2018) presented the distinct seasons of this

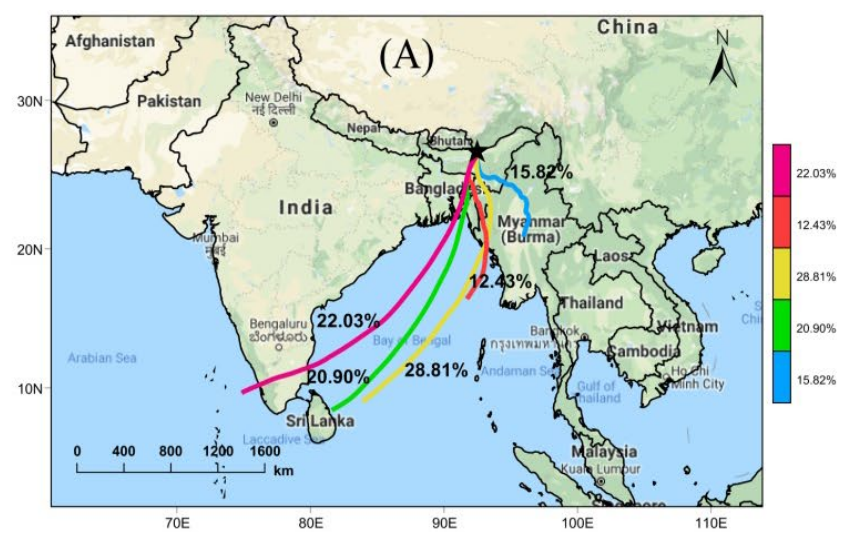

region as per India Meteorological Department (IMD), which are Winter (January-February), Pre-monsoon (MarchMay), Monsoon (June-September), and Post-monsoon (October-December).

\section{Sampling}

Rainwater samples were collected on the Tezpur University campus characterized as a remote, rural background location. The collections were done on an event basis for three consecutive years (2012, 2013, and 2014) using a high density $20.7 \mathrm{~cm}$ diameter polypropylene funnel fitted onto a $2 \mathrm{~L}$ high density polypropylene bottle. The rain sampler was positioned on the rooftop (10 $\mathrm{m}$ from ground) and the collector height was maintained at $1 \mathrm{~m}$ above the resting surface to avert contamination of samples from splashes as per Rastogi and Sarin (2005).

Measurements of $\mathrm{pH}$, electrical conductivity (EC), and volume were taken immediately in the laboratory after each rain event. It was then filtered to remove any insoluble materials. Two aliquots were stored for further analyses. One was used for the determination of anions and the other was for cations. It was treated with chloroform to minimize microbial degradation of ions such as ammonium and stored at $4^{\circ} \mathrm{C}$ (Keene et al., 1983; WMO, 2004).

For the analysis of carbon, filtered samples were stored in brown vials at $4^{\circ} \mathrm{C}$ to avert degradation of organics till analysis (Willey et al., 2000; Kieber et al., 2002; Campos et al., 2007). This campaign included 285 rain events $(2012=$ $116,2013=102$, and $2014=67)$.

\section{Chemical Analyses}

The $\mathrm{pH}$ of rain samples was measured with a glass electrode $\mathrm{pH}$ meter (Sartorius, PT 10), which was calibrated with standard buffer solutions of $\mathrm{pH} 4$ and 7(NIST) prior measurements. The conductivity meter (Systronics, 304) was periodically calibrated using $0.1 \mathrm{~N} \mathrm{KCl}$ (aqueous) solution. The ions were analyzed by an ion chromatograph (IC) (Metrohm, 882). The anion column, Metrosep A Supp 5 250/4.0 and the cation column Metrosep C4-150/4.0 were used with standard protocols for analyses of anions and cations, respectively (Bhuyan et al., 2016, 2018).

The formic and acetic acids were measured using the

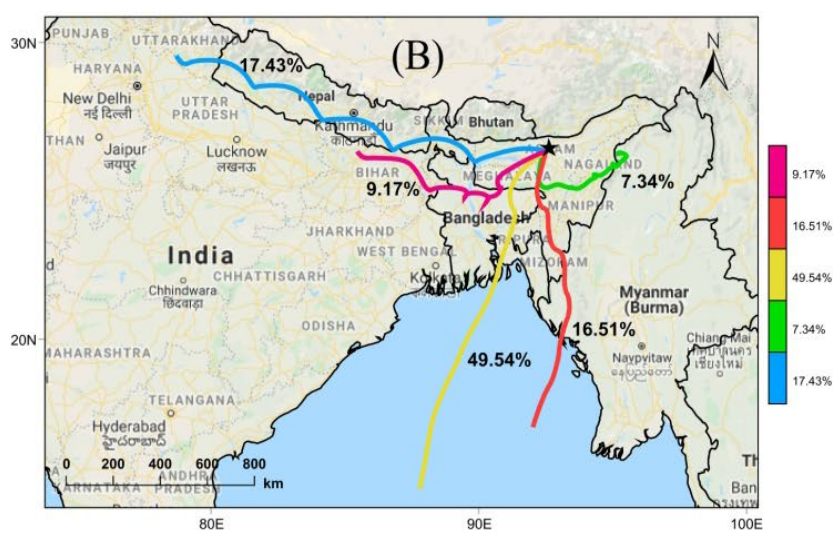

Fig. 1. Back trajectory clusters reaching the sampling station (Tezpur) of Brahmaputra Valley: (A) Monsoon and (B) Non monsoon (the color scales (blue-magenta) represent trajectories 1-5). 
Metrosep Organic Acids-100/7.8 and a standard eluent (0.5 mmol L $\mathrm{m}^{-1} \mathrm{H}_{2} \mathrm{SO}_{4}$ :Acetone :: 85:15). The DOC was measured with a TOC analyzer (Multi NC/2100, Analytikjena make, Germany) with a non-dispersive infrared (NDIR) detector as per Bhuyan et al. (2016).

\section{Airmass Back Trajectory and Clustering}

Daily 120-hr trajectories at starting height of $500 \mathrm{~m} \mathrm{agl}$ reaching Tezpur were calculated from Reanalysis Data downloaded from the Gridded Meteorological Data Archives (ready.noaa.gov/archives.php). The HYSPLIT back trajectory clusters have been computed using GIS based software TrajStat (Wang et al. 2009).

\section{Data Quality}

Quality assurance/quality control (QA/QC) procedures were followed for the precipitation chemistry monitoring. Samples contaminated with direct leaf fall or bird droppings were excluded. The bottles and funnels were pre-washed with ultrapure water (Ultrapure Type 1, Simplicity, Millipore, resistivity $18.2 \mathrm{M} \Omega . \mathrm{cm}$ ) before sampling. The collectors were deployed just before the start of rain and removed immediately after the rain stopped. Field blanks were evaluated frequently and analyzed for all the parameters by the same procedures as the rain samples. Field blanks were taken by pouring ultra-pure water into the sampler and following the procedures as previously described. The sample values were adjusted by subtracting the field blank values. Replicate measurements were also conducted for the samples that showed $\mathrm{RSD} \leq 5 \%$. In case of $\mathrm{pH}$, the difference between replicate measurements were found to be less than 0.05 while for EC, they were less than $1 \mu \mathrm{S} \mathrm{cm}^{-1}$.

The ion balance was evaluated by linear regression analysis between sum of anions and sum of cations. The result showed a good correlation between total anions and cations $(\mathrm{r}=0.876)$, which was significant at $\mathrm{p}<0.01$ (Fig. 2). The slope $(\mathrm{m}=1.546)$ deviated to the higher side of ideal 1:1 relationship, which would mean that more anions were missed from the analyses, e.g., phosphate, organic acids. Also, in the assessment of ion balance, bicarbonate $\left(\mathrm{HCO}_{3}{ }^{-}\right)$ and hydrogen ion $\left(\mathrm{H}^{+}\right)$concentrations were also considered by indirectly estimating their concentrations from the $\mathrm{pH}$ values. $\mathrm{HCO}_{3}{ }^{-}$was estimated using the relationship between $\mathrm{pH}$ and $\mathrm{HCO}_{3}{ }^{-}$(Granat, 1972) explained by Eq. (1):

$$
\left[\mathrm{HCO}_{3}^{-}\right]=10^{(-11.24+\mathrm{pH})}
$$

The volume weighted mean concentrations (VWM) were calculated to eliminate the influence of different rainfall intensities on the $\mathrm{pH}$ (Ge et al., 2011). The VWM pH was calculated as per Eq. (2):

$$
\mathrm{pH}_{V W M}=-\log \left(\frac{\sum\left(10^{-\mathrm{PH} i}\right) \times V i}{\sum \mathrm{V} i}\right)
$$

where $\mathrm{pH}_{V W M}$ is the volume weighted average $\mathrm{pH}$, and $\mathrm{pH} i$ and $\mathrm{V} i$ are the value of $\mathrm{pH}$ and volume of the sample $i$, respectively. The volume weighted mean concentrations (VWM) of ionic constituents were calculated using Eq. (3):

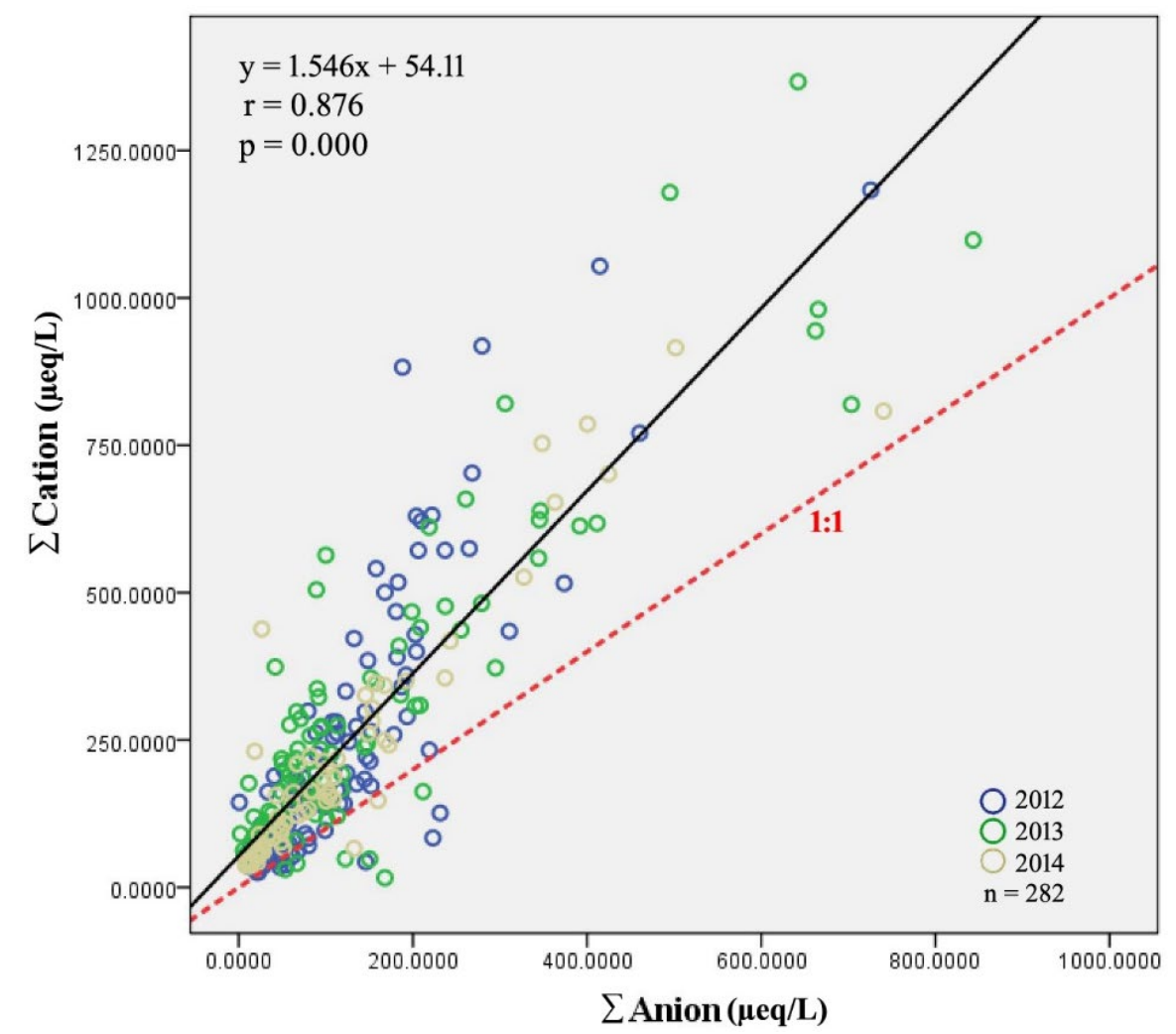

Fig. 2. Relationship between $\sum$ Anion and $\sum$ Cation during the study period 2012-14. 


$$
\operatorname{VWM}\left(\mu \mathrm{eq} \mathrm{L} \mathrm{L}^{-1}\right)=\frac{\sum_{i=1}^{n} C i P i}{\sum_{i=1}^{n} P i}
$$

where $\mathrm{C} i$ is the ionic concentration of each ion in $\mu \mathrm{eq} \mathrm{L}^{-1}$, $\mathrm{P} i$ is the volume of each rainy event in $\mathrm{ml}$, and ' $\mathrm{n}$ ' is the number of samples. VWM takes into account the effect of dilution by the rainfall amount and it is useful in comparative studies of rain events. The data were scrutinized for extreme values.

\section{Positive Matrix Factorization (PMF)}

PMF is widely applied for source apportionment studies of environmental pollutants present in various matrices. Previous work has successfully applied PMF for the apportionment of rainwater chemical constituents (e.g., Juntto and Paatero, 1994; Anttila et al., 1995; Rao et al., 2016). From the rainwater constituent concentrations in micro-equivalents per liter, total deposition per event values were calculated as concentration ( $\mu$ eq $\mathrm{L}^{-1}$ ) of species in a given event times the total volume (L) collected during that event. These values were used in the PMF model (EPA PMF 5.014). The model requires uncertainties for each data point, which were calculated as per Anttila et al. (1995), and an additional model uncertainty of $5 \%$ was added. The agreement of the number of factors was reached on getting symmetrical residuals, within \pm 3.0 for each chemical parameter, and the solution with interpretable factors was accepted. The identification of the factors was decided considering species with minimum displacements (DISP) of concentrations.

The errors, which were estimated by displacement (DISP) and bootstrap (BS) methods, were acceptable for the solution. The DISP analysis did not have any swaps and there were no unmapped factors found in the BS analysis.

\section{RESULTS AND DISCUSSION}

\section{Chemistry of Rainwater $p H$}

The arithmetic and volume weighted (VW) mean $\mathrm{pH}$ and EC of rainwater observed during the study period are given in Supplementary Table S1. The mean $\mathrm{pH}$ for the entire study period was found to be 5.66 and ranged from 4.51 to 7.68. The VW mean $\mathrm{pH}$ was 5.16. The yearly means of $\mathrm{pH}$ were found to decrease in the order of 2012 (5.87), 2013 (5.63), and 2014 (5.35). The difference of means was found to be significant $(\mathrm{F}=13.802 ; \mathrm{p}=0.000)$. The frequency distribution of $\mathrm{pH}$ has been illustrated in Fig. 3 showing that most rain events were in the $\mathrm{pH}$ range of 5.5 to 6.0, which pointed at near the alkaline nature of the rainwater.

Rain events characterized by low $\mathrm{pH}(<5.6)$ often have significant contributions from $\mathrm{NO}_{3}{ }^{-}$and $\mathrm{SO}_{4}{ }^{2-}$ (e.g., Rastogi and Sarin, 2005). In the sample having the lowest $\mathrm{pH}$ (4.51), $\mathrm{NO}_{3}{ }^{-}$and $\mathrm{SO}_{4}{ }^{2-}$ contributed $33 \%$ and $55 \%$, respectively, of the total anion concentrations and $\mathrm{HCO}_{3}{ }^{-}$ion concentrations were negligible. $\mathrm{NH}_{4}{ }^{+}$and $\mathrm{Ca}^{2+}$ contributed $38 \%$ and $18 \%$, respectively, to the total cation concentrations. The difference

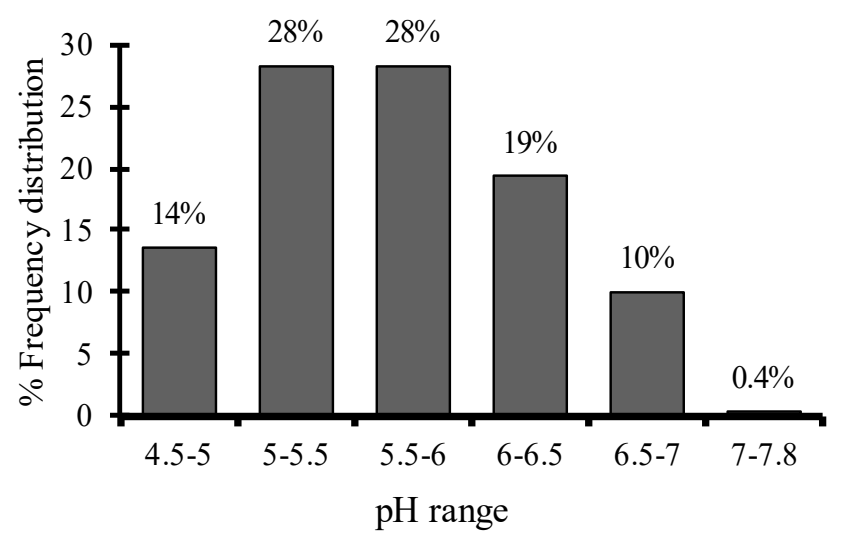

Fig. 3. Percentage frequency distribution of rainwater $\mathrm{pH}$ in Tezpur.

in the free acidity, i.e., $\mathrm{H}^{+}$between the sample having the lowest $\mathrm{pH}\left[\mathrm{H}^{+}=30.90 \mu \mathrm{eq} \mathrm{L}^{-1} ; \mathrm{pH}=4.51\right]$ and natural rainwater in equilibrium with atmospheric $\mathrm{CO}_{2}\left[\mathrm{H}^{+}=2.51 \mu \mathrm{eq} \mathrm{L} \mathrm{L}^{-1} ; \mathrm{pH}=\right.$ 5.61] (Tiwari et al., 2015) is $28.39 \mu \mathrm{eqL} \mathrm{L}^{-1}$. This difference would suggest the influence of strong acidic components like $\mathrm{NO}_{3}{ }^{-}, \mathrm{SO}_{4}{ }^{2-}$, and $\mathrm{Cl}^{-}$derived from anthropogenic activities, and it also indicates minimum neutralization of these acids by alkaline ions in the atmosphere. A year-long study of water-soluble ions in airborne PM (sampled during 201213) across the Tezpur region also revealed high loading of $\mathrm{SO}_{4}{ }^{2-}$ and $\mathrm{Cl}^{-}$(Bhuyan et al., 2016b) that might have been scavenged by rainfall.

The sample with the highest $\mathrm{pH}$ (7.68) had high contributions from $\mathrm{Ca}^{2+}(64 \%)$ and $\mathrm{NH}_{4}{ }^{+}(16 \%)$ to the total cation concentration, with $\mathrm{HCO}_{3}{ }^{-}$representing $63 \%$ of the total anions and $\mathrm{NO}_{3}{ }^{-}$and $\mathrm{SO}_{4}{ }^{2-}$ contributing $11 \%$ and $18 \%$, respectively, to the total anions.

The monthly variations in $\mathrm{pH}$ against volume rainwater are shown in Fig. 4. The months that experienced very low rainfall volume and/or rain events that came after a long spell of dry days were found to have higher $\mathrm{pH}$ values suggesting that crustal dust raised the rainwater $\mathrm{pH}$ during the dry periods. March to September experience high rainfall and showed uniform $\mathrm{pH}$ values. After long and continuous rainy periods, the $\mathrm{pH}$ decreased in the subsequent samples due to lack of enough alkaline ions in the atmosphere.

\section{$E C$}

The VW-mean EC was $16.22 \mu \mathrm{S} \mathrm{cm}^{-1}$ and the arithmetic mean was $29.16 \mu \mathrm{S} \mathrm{cm}^{-1}$. The monthly variation of EC against volume of rainwater is shown in Fig. 4. The EC of the rain events decreased with the increasing rainfall volume. Thus, after continuous, heavy rainfall, the particles and gases contributing to the EC of rainwater decreased because of 'washing and cleaning' the atmosphere.

\section{Ions}

The equivalence ratio, sum of the anions to sum of the cations ( $\sum$ Anion/ $/$ Cation) and the indicator of the completeness of measured major constituents (Wang and Han, 2011), was found to be 0.78 , suggesting that most of the major anions and cations were measured. It was observed 


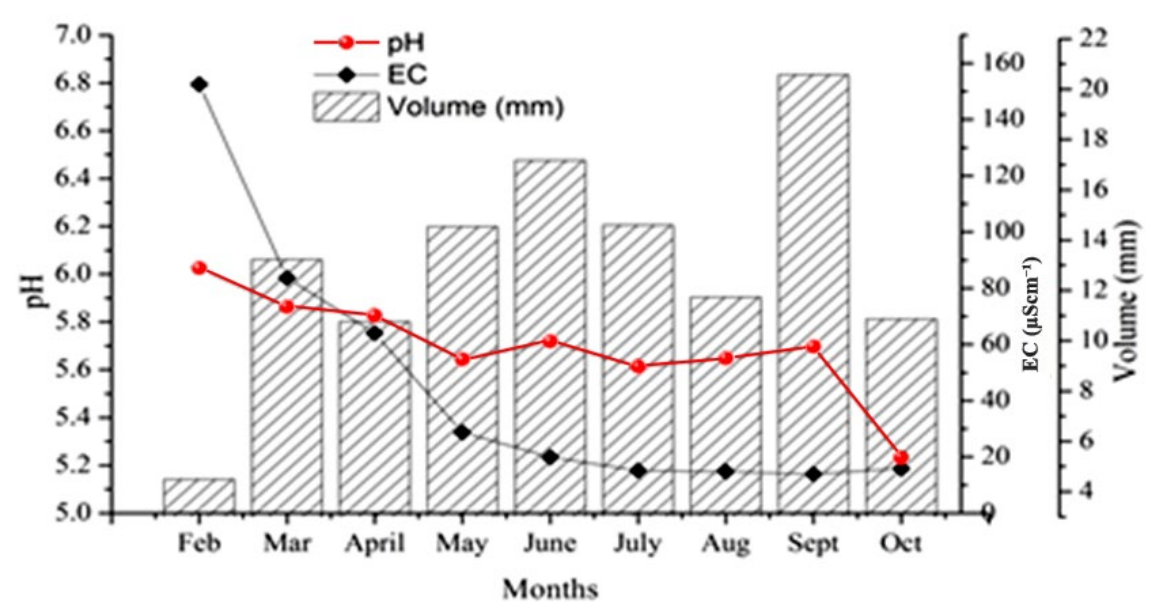

Fig. 4. Temporal variation of mean $\mathrm{pH}$ and $\mathrm{EC}\left(\mu \mathrm{S} \mathrm{cm}^{-1}\right)$ along with average volume $(\mathrm{mm})$ of rainwater collected during the study period.

that the arithmetic means were greater than the VW mean concentrations, which might mean that higher concentrations are usually associated with lower volume of precipitation as reported by (Xiao, 2016). On average, the ionic representation of rain samples followed the order of $\mathrm{NH}_{4}{ }^{+}>\mathrm{Ca}^{2+}>\mathrm{SO}_{4}{ }^{2-}>$ $\mathrm{NO}_{3}{ }^{-}>\mathrm{Cl}^{-}>\mathrm{Na}^{+}>\mathrm{K}^{+}>\mathrm{Mg}^{2+}>\mathrm{H}^{+}>\mathrm{HCO}_{3}{ }^{-}>\mathrm{Br}^{-}>\mathrm{F}^{-}>\mathrm{Li}^{+}$.

A comparison of the concentrations with the reported studies from elsewhere in India has been put up in Table S1. It was observed that the VWM concentration of acid buffering ions (i.e., $\mathrm{Ca}^{2+}, \mathrm{Mg}^{2+}$, and $\mathrm{HCO}_{3}{ }^{-}$) in rainwater showed much higher values in the rainwater of the arid regions of India such as Ahmedabad (Rastogi and Sarin, 2005), Pune (Rao et al. 2016), and the Indo-Gangetic Plain (IGP) (Tiwari et al., 2015). A similar pattern was observed for the acidic ions, $\mathrm{SO}_{4}{ }^{2-}$ and $\mathrm{NO}_{3}{ }^{-}$, from Pune and the IGP when compared to our study. Higher acidic ions $\left(\mathrm{SO}_{4}{ }^{2-}\right.$ and $\left.\mathrm{NO}_{3}{ }^{-}\right)$were reported from the upper Brahmaputra (Jorhat) area of Assam (Kulshrestha et al., 2014), compared to the current results. The present study found that alkaline ions $\left(\mathrm{Ca}^{2+}, \mathrm{NH}_{4}{ }^{+}\right)$were dominant during the entire study period. $\mathrm{Ca}^{2+}$ and $\mathrm{NH}_{4}{ }^{+}$ contributed $18 \%$ and $17 \%$, respectively, while $\mathrm{SO}_{4}{ }^{2-}$ and $\mathrm{NO}_{3}{ }^{-}$provided $12 \%$ and $11 \%$, respectively, to the total ion budget (Fig. 2). So, $\mathrm{SO}_{4}{ }^{2-}$ acted as a dominant acidic ion in the study region followed by $\mathrm{NO}_{3}{ }^{-}$. This result would suggest that most of the associations between these alkaline and acidic species might be in the form of neutral salts such as $\left(\mathrm{NH}_{4}\right)_{2} \mathrm{SO}_{4}, \mathrm{NH}_{4} \mathrm{NO}_{3}, \mathrm{CaSO}_{4}$, and $\mathrm{Ca}\left(\mathrm{NO}_{3}\right)_{2}$. The presence of $\mathrm{Ca}^{2+}$ could be soil derived from construction activities, and/or might be due to the long-range transport from more arid regions. $\mathrm{Cl}^{-}$and $\mathrm{Na}^{+}$, markers of sea salt, also contributed averages of $18 \%$ and $8 \%$, respectively, to the total ion balance of rainwater during the entire study period.

To appreciate the influence of season in rainwater composition, the relationship between measured $\mathrm{Na}^{+}$and $\mathrm{Cl}^{-}$ ions of each event with reference to seawater $\mathrm{Cl}^{-} / \mathrm{Na}^{+}$have been plotted in supplemental Fig. S1. It was observed that the relationship was poor, except for the year 2014. During 2012 and 2013, scattered distributions were observed with an excess of $\mathrm{Cl}^{-}$in 2013, and an excess of $\mathrm{Na}^{+}$in 2012. The excess of $\mathrm{Cl}^{-}$could have come from additional source contributions like biomass burning and open waste burning, and/or as a reflection of $\mathrm{Cl}^{-}$displacement from sea-salts $(\mathrm{NaCl})$ by anthropogenic $\mathrm{HNO}_{3} / \mathrm{H}_{2} \mathrm{SO}_{4}$ (Sarin et al., 2010). $\mathrm{K}^{+}$, the signature ion of biomass burning, contributed $6 \%$, $9 \%$, and $8 \%$ to the total ionic budget during 2012, 2013, and 2014, respectively. These results indicate the prevalence of biomass burning and its impact on regional atmospheric chemistry.

Among the two organic acids, formic acid showed the higher average concentration during the study period with a value $19.8 \mu \mathrm{eq} \mathrm{L}^{-1}$. The ratio of acetate to formate $(\mathrm{A} / \mathrm{F})$ can signify the degree of photochemical production $(\mathrm{A} / \mathrm{F}<1)$ of these acids against their primary emissions $(\mathrm{A} / \mathrm{F}>1)$; (Sunder Raman et al., 2008 and references therein). The samples of the pre-monsoon seasons were observed to have ratios $>1$, and rains during all other seasons were observed to have ratios $<1$. The pre-monsoon season is the time when the brick kilns are at their peak of production, which means that the combustion of coal is at its maximum and adding significant organic acid primary emissions. Increased Dissolved Organic Carbon (DOC) concentrations were seen during 2013 (8.43 $\left.\mathrm{mgC} \mathrm{L}^{-1}\right)$. The presence of organic carbon constituents could be attributed to various source contributors. Organic carbon particles emitted from biomass burning, intensive coal combustion, or formation in the atmosphere during long-range transport could account for their presence (Deka and Hoque, 2014b).

\section{Seasonal Variability}

Seasonal variations in the ionic composition were observed (Fig. S2). Concentrations of ions except $\mathrm{Cl}^{-}$followed the order: Pre-monsoon $>$ Winter $>$ Post-monsoon $>$ Monsoon. This trend shows that pre-monsoon and winter are the two seasons that experienced maximum concentrations of most ions. Winter season receives substantially less rainfall (2013, n $=2 ; 2014, \mathrm{n}=2$ ) compared to the monsoon season. However, most of the industrial activities (brick kilns, tea industries, stone quarries, construction, etc.) peak during winter and are sustained until the region receives monsoonal showers. Therefore, the pre-monsoon season behaves like 
winter until Nor'wester showers begin. The rainfall received during these seasons is more concentrated with pollutants that have been emitted from local sources. Monsoon receives the highest rainfall. As the monsoon proceeds, the atmosphere becomes cleaner due to efficient scavenging of particles. Therefore, there are decreased concentrations of all the ions during the monsoon and post-monsoon seasons.

It was observed that $\mathrm{Cl}^{-}$showed maximum concentration i.e., $65.5 \mu \mathrm{eq} \mathrm{L}^{-1}$ during the pre-monsoon period. Among other ions concentrations, $\mathrm{SO}_{4}{ }^{2-}$ reached its during winter.

The seasonal variability in the composition of rainwater may also be related to long-range transport. There is an explicit shift of directions from where the air mass trajectories that reached Tezpur originate in different seasons. Trajectory clusters reaching Tezpur of Brahmaputra Valley at $500 \mathrm{~m}$ height above ground level for monsoon and non-monsoon period illustrated in Fig. 1 and the associated concentrations (Table 1) show that air masses travelled over long distances and from different directions. During monsoons (JuneSeptember), the trajectories come mainly from the Bay of Bengal and the Arabian Sea. During this period, trajectories crossed the landmass the deccan plateau of India and Bangladesh. The concentrations of the species were higher in the non-monsoon period and those rains were associated with the clusters that originated from and/or crossed the polluted regions like the IGP.

The calculated anthropogenic contribution of the chemistry was found to be much higher during the non-monsoon period. The clusters 1 and 5 represent airmasses arriving from the polluted IGP region and, therefore, the associated anthropogenic contributions were found to be maximum. It is also evident that the contribution of dust was higher during the non-monsoon period. So, the chemistry suggests that both local and trans-boundary movement of pollutants with the rain bearing airmasses did influence the rainwater chemistry of the study area.

Differences in the chemical properties of pollutants influenced the rainwater chemistry. It was found that alkaline ions $\left(\mathrm{Ca}^{2+}, \mathrm{NH}_{4}^{+}, \mathrm{K}^{+}\right)$were mostly locally driven, and maintained the alkaline nature of rainwater during most of the year even with substantial sources of acidic compounds. During non-monsoon seasons, rainwater composition was dominated by $\mathrm{Ca}^{2+}, \mathrm{NH}_{4}{ }^{+}, \mathrm{K}^{+}, \mathrm{SO}_{4}{ }^{2-}$ and $\mathrm{NO}_{3}{ }^{-}$that originated locally from the sources like soil suspended from roads and agricultural fields, biomass burning, automobiles, and local industries like brick kilns. However, the monsoonal rain chemistry differs from the rest of the period. This period receives much greater amounts of rainfall originating from sea and crossing the land. Air masses reaching the study site during other periods have been found to have originated from distant places like Northern India as well as South Asia (Fig. 1).

\section{Deposition Flux of Ions}

The annual wet deposition (WD) was calculated using the approach of Akpo et al. (2015). The WD was expressed in $\mathrm{kg} \mathrm{ha}^{-1} \mathrm{yr}^{-1}$ and was calculated by multiplying the VW mean value in $\mathrm{mgL}^{-1}$ by the annual average rainfall amount ( $\mathrm{P}$ in $\mathrm{mm})$.

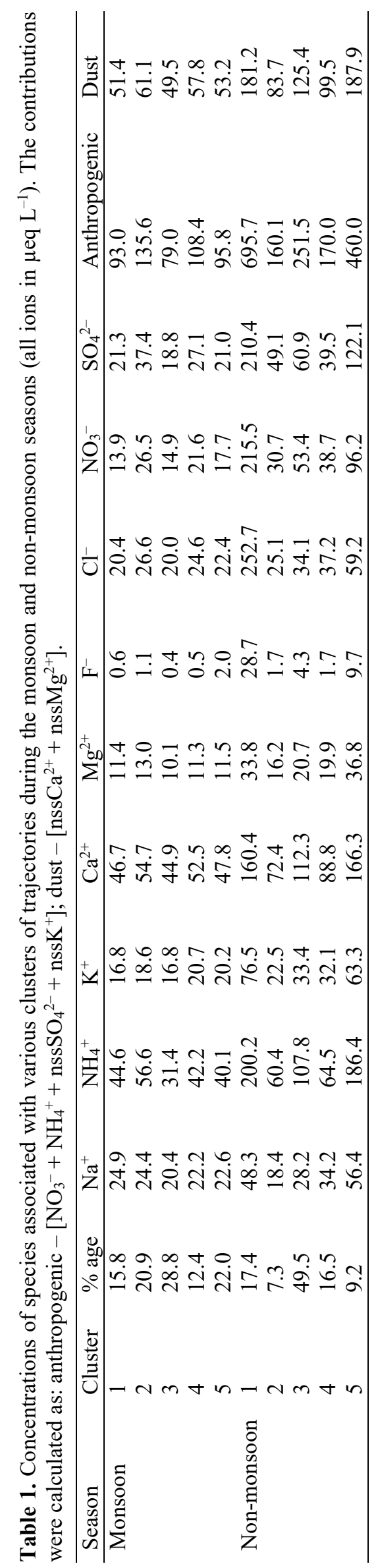


$\mathrm{WD}\left(\mathrm{kg} \mathrm{ha}^{-1} \mathrm{yr}^{-1}\right)=\mathrm{VWM}\left(\mathrm{mgL}^{-1}\right) \times \frac{P}{100}$

The annual wet deposition along with the standard deviations and annual total rainfall collected during the study period over the mid-Brahmaputra valley are given in Table S2. It has been observed that $\mathrm{SO}_{4}{ }^{2-}$ and $\mathrm{NO}_{3}{ }^{-}$among the anions, and $\mathrm{Ca}^{2+}$ and $\mathrm{NH}_{4}{ }^{+}$among the cations were important ionic constituents in terms of wet deposition. The study year 2014 showed comparatively higher deposition of most ions except for $\mathrm{Cl}^{-}, \mathrm{Br}^{-}$, and $\mathrm{F}^{-}$. Deposition of $\mathrm{Na}^{+}$ion was almost equal in all the three years. Among the measured ions, $\mathrm{K}^{+}, \mathrm{NH}_{4}^{+}, \mathrm{F}^{-}, \mathrm{Cl}^{-}, \mathrm{NO}_{3}{ }^{-}$, and $\mathrm{SO}_{4}{ }^{2-}$ showed significant difference (one-way ANOVA) in terms of wet deposition at 0.05 significant levels having $\mathrm{p}$ values $0.03,0.00,0.00,0.00$, $0.00,0.01$ respectively. The ions showed highest deposition flux during pre-monsoon seasons followed by winter (Fig. 5). The global assessment of precipitation chemistry and deposition under the World Meteorological Organization (WHO) Global Atmosphere Watch (GAW) reported that Northeast India has been prone to nitrogen and sulfur deposition compared to industrial sites like western Europe, northeastern United States, and East Asia (Vet et al., 2014). Deposition of high sulfur and nitrogen compounds in this region could be associated with the high precipitation depths reported by the WHO-GAW.

\section{Acidity and Neutralization}

The acidity of rainwater is strongly dependent on the concentrations of (i) acid-forming ions like $\mathrm{SO}_{4}{ }^{2-}, \mathrm{NO}_{3}{ }^{-}, \mathrm{Cl}^{-}$, and organic acids, and (ii) alkaline species such as $\mathrm{NH}_{4}{ }^{+}$, $\mathrm{Ca}^{2+}$, and $\mathrm{Mg}^{2+}$ responsible for neutralization of the acidity. The capacity of acid neutralization is calculated as fractional acidity (FA), i.e., $\mathrm{FA}=\mathrm{H}^{+} /\left(\mathrm{NO}_{3}{ }^{-}+\mathrm{SO}_{4}{ }^{2-}\right)$ (Balasubramanian et al., 2001). A value of $\mathrm{FA}=1$ indicates rainwater acidity generated by $\mathrm{SO}_{4}{ }^{2-}$ and $\mathrm{NO}_{3}{ }^{-}$has not been neutralized at all by other ions. The FA value for the entire study period was 0.06 . This value indicates that about $94 \%$ of the acidity caused by mineral acids was neutralized by alkaline species. There is a $6 \%$ gap in terms of species that caused the rainwater acidification that could be due to the species other than $\mathrm{NO}_{3}{ }^{-}$ and $\mathrm{SO}_{4}{ }^{2-}$.
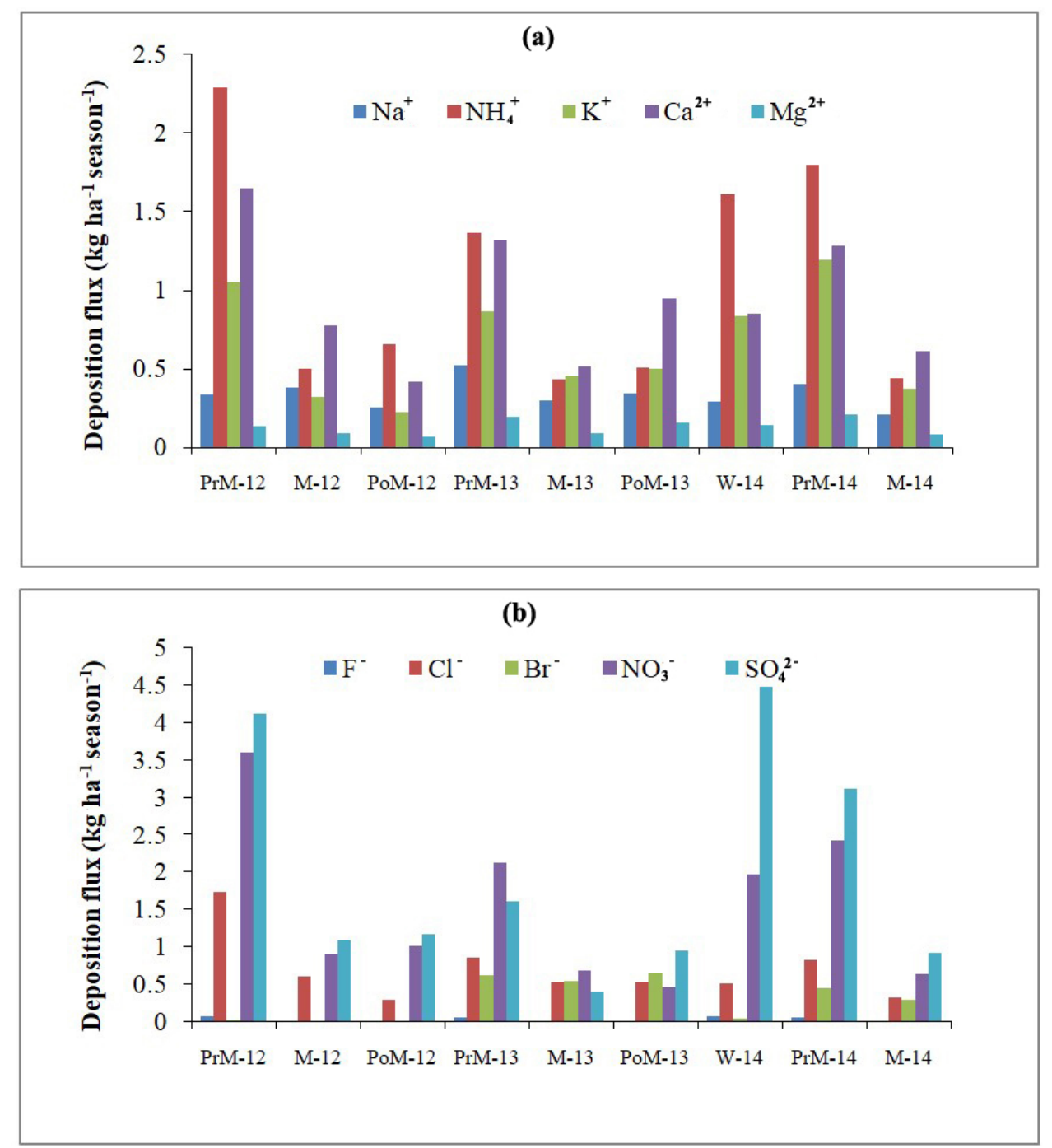

Fig. 5. Seasonal deposition flux of ions (PrM - Premonsoon, M - Monsoon, PoM - Postmonsoon, W - Winter). 
The $\left(\mathrm{Ca}^{2+}+\mathrm{NH}_{4}{ }^{+}+\mathrm{Mg}^{2+}\right) /\left(\mathrm{NO}_{3}{ }^{-}+\mathrm{SO}_{4}{ }^{2-}\right)$ ratio was greater than one $(=1.76)$ during the entire study period indicating that there were sufficient alkaline species present to neutralize the acidity. The relative contribution of $\mathrm{NO}_{3}{ }^{-}$to the acidity was calculated by $\mathrm{NO}_{3}^{-} /\left(\mathrm{NO}_{3}{ }^{-}+\mathrm{nssSO}_{4}{ }^{2-}\right)(\mathrm{Cao}$ et al., 2009). The result was found that $42 \%$ of rainwater acidity was caused by $\mathrm{NO}_{3}{ }^{-}$and $58 \%$ was due to $\mathrm{SO}_{4}{ }^{2-}$. Thus, $\mathrm{NO}_{3}{ }^{-}$also played a major role in the acidification of rainwater. $\mathrm{NO}_{3}{ }^{-}$in rainwater could be due to the homogeneous and heterogeneous gas-phase transformations of $\mathrm{NO}_{\mathrm{x}}$ to $\mathrm{HNO}_{3}$, followed by reactions with basic ions such as $\mathrm{NH}_{3}$ to form $\mathrm{NH}_{4} \mathrm{NO}_{3}$ (Akpo et al., 2015).

Neutralizing factors for $\mathrm{Ca}^{2+}, \mathrm{NH}_{4}{ }^{+}, \mathrm{K}^{+}$and $\mathrm{Mg}^{2+}$ have been calculated using Eq. (5):

$$
\mathrm{NF}_{\mathrm{X}}=[\mathrm{X}] /\left[\mathrm{NO}_{3}{ }^{-}+\mathrm{SO}_{4}{ }^{2-}\right]
$$

where X stands for component of interest (Das et al., 2005). Fig. S3 illustrates the annual and seasonal variations in the neutralization factors for the major alkaline ions. The ions followed the order $\mathrm{Ca}^{2+}>\mathrm{NH}_{4}^{+}>\mathrm{K}^{+}>\mathrm{Mg}^{2+} . \mathrm{Ca}^{2+}$ was found to be the most neutralizing alkaline ion present in the rainwater followed by $\mathrm{NH}_{4}{ }^{+}$. This order of neutralization agrees with most studies reporting from different geographical locations of India (Parashar et al., 1996; Kulshrestha et al., 2003; Das et al., 2005; Rastogi and Sarin, 2005; Budhavant et al., 2009; Budhavant et al., 2011; Tiwari et al., 2015). Fig. S3 shows the neutralization factors of major cations during different seasons of the study period.

\section{Source Apportionment of the Rainwater Constituents}

PMF was employed to investigate the sources and the chemistry of the composition of rain. A solution with six factors was obtained, which was the best fit in terms of the distributions of scaled residuals and had reasonable physical interpretation (Fig. 6). The displacement approach (DISP) was used to explore the rotational ambiguity in the solution (Paatero et al., 2014). Individual values in the profiles were pulled away from the best fit values until the objective function value, Q, rose beyond a specified limit. Also pulling on a value should not cause the factors to change identities ("factor swapping"). The mean DISP value is indicated in Fig. 6 by the open circles and the minimum and maximum values are denoted by the error bars.

Factor 1: This factor has contributions from $\mathrm{Na}^{+}$and $\mathrm{Cl}^{-}$, with high explained variation (EV), that is typically attributed to sea-salt (Rao et al., 2016). This result suggests the mixing of sea salt with crustal dust while being transported from the sea to the study area. The monsoon season airmass back trajectories (Fig. 1) show that they originated from the Bay of Bengal, and the Arabian Sea, travelling over Bangladesh and India's mainland before reaching the study area. In the process, the air was well mixed and included local dust inputs. Also, during the monsoon, a large volume of crustal debris, which is carried by the runoff water from the hills, settled on the roads. Following the rainy days, the sunny, dry days allow the dust to dry and moving vehicles then suspend the dry debris into the air (Bhuyan et al., 2018). This process is more pronounced in the case of unpaved village roads where the rain loosens the surface of the road leading to greater release of crustal matter from such roads on dry days.

Factor 2: The principal contributors to this factor were $\mathrm{F}^{-}$, $\mathrm{Ca}^{2+}, \mathrm{Mg}^{2+}$, and $\mathrm{NH}_{4}^{+}$, and organic acids. The spread of DISP values for these species are very small demonstrating that they are important species in this profile. This factor makes large contributions (EV) to these species including $100 \%$ of the $\mathrm{F}^{-}$. $\mathrm{F}^{-}$has been reported as a marker species for coal burning (e.g., Ando et al., 1998, 2001), and $\mathrm{F}^{-}$appears only in this factor. Thus, this factor can be attributed to emission from coal combustion. $\mathrm{Ca}$ and $\mathrm{Mg}$ are important components of fly ash in Indian coal. Jala and Goyal (2006) reported that the fly ash collected by an electrostatic precipitator had a Ca content of $3.4 \%$ and a $\mathrm{Mg}$ concentration of $0.14 \%$. Some ammonia is also emitted from coal burning (e.g., Bouwman et al., 1997). However, most of the ammonia comes from agricultural sources. The major users of coal are the brick kilns and the tea processing units, where coal is used to generate heat for drying. Brick kilns in this region operate mostly during post monsoon and winter periods and reduce their activity with the coming of pre-monsoon showers. Alternatively, tea processing intensifies during the pre-monsoon and monsoon periods since this time of the year is the main growing period for tea plants and this is the period of the year when the region receives maximum rainfall. Also, brick industries operating in neighboring Bangladesh ( 1000 units just around Dhaka city alone) by burning Indian coal and agricultural wastes (Guttikunda et al., 3013). Back trajectory analysis (Fig. 1) suggests that trajectories that originate and/or pass over Bangladesh could bring emissions to the region. The presence of $\mathrm{HCOO}^{-}$and $\mathrm{CH}_{3} \mathrm{COO}^{-}$(with high EV) may be attributed to the start-up and burn-out phases of the coal burning cycle where secondarylike species are emitted (Li et al., 2019). The analysis of the ratios of the acids $(\mathrm{F} / \mathrm{A})$ provides signs of primary emission, which appears to be coal burning.

Factor 3: This factor has representation of $\mathrm{K}^{+}, \mathrm{Cl}^{-}$, $\mathrm{HCOO}^{-}$and $\mathrm{CH}_{3} \mathrm{COO}^{-}$and DOC. $\mathrm{K}^{+}$is a marker species of biomass burning emissions (Wang et al., 2011; Masiol et al., 2017). It has also been reported that $\mathrm{K}^{+}$associated with $\mathrm{Cl}^{-}$ could be typical of biomass burning emission. Sillapapiromsuk et al. (2013) reported extremely high emission factors for $\mathrm{K}^{+}$ and $\mathrm{Cl}^{-}$compared to other ions from crop residue burning experiments. Deka and Hoque (2015) had found $\mathrm{K}^{+}$and $\mathrm{Cl}^{-}$ to be the most abundant species, several, hundred $\mathrm{mg} \mathrm{kg}^{-1}$, in biomass burning smoke particles collected from rural kitchens of the Brahmaputra Valley.

Although $\mathrm{HCOO}^{-}$and $\mathrm{CH}_{3} \mathrm{COO}^{-}$are the oxidized byproducts of atmospheric VOC degradation, much of which are biogenic (e.g., Chaliyakunnel et al., 2016 and references therein), there are also reports of primary emission of them from biomass burning (Talbot et al., 1988). They hypothesized that the seasonality of $\mathrm{HCOO}^{-}$and $\mathrm{CH}_{3} \mathrm{COO}^{-}$could be an outcome of differential contributions of biogenic burning versus anthropogenic emissions. Emission of very large volumes of organic species is very typical of biomass burning as is evident in the association of DOC with the markers of biomass burning. Crutzen and Andreae (1990) reported that biomass burning is responsible for emission of 


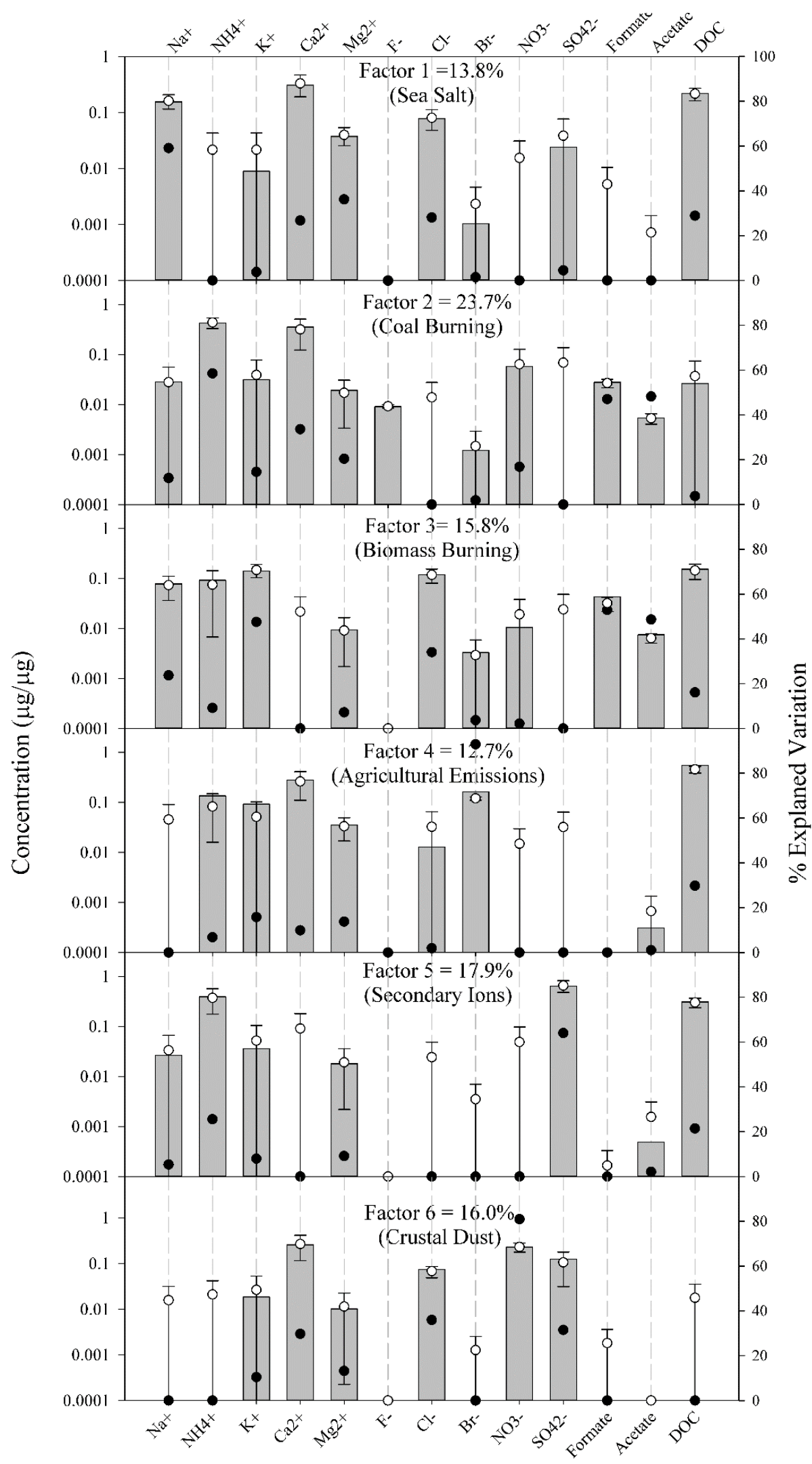

Fig. 6. Factors extracted by EPA PMF 5.0: The bars are the base case values. The displacement (DISP) results as open circles with error bars showing max and min values. Solid points are the explained variations. The variables with maximum explained variations and small DISP intervals of concentrations are considered for identifying the sources associated with factors. (Factor 1- Sea Salt, Factor 2- Coal burning (industries), Factor 3- Biomass burning, Factor 4- Agricultural emission, Factor 5- secondary ions, Factor 6- Crustal dust). 
a huge volume of trace gases into the atmosphere, especially $\mathrm{CO}$, methane, and non-methane hydrocarbons. These hydrocarbons undergo photochemical oxidation initiated by hydroxyl radical attack and as a result several oxidized forms of organics are formed in the atmosphere. The oxidized organics tend to be water soluble, and it is expected that they are readily scavenged by the water droplets. Additionally, carboxylic acids tend to enhance CCN activities (Kumar et al., 2003).

Formate and some $\mathrm{CH}_{3} \mathrm{COO}^{-}$are major products of methane combustion in $\mathrm{CNG}$ vehicles, which are in use in the major cities in mainland India and not around the study area of India's northeastern states. The nearest areas with CNG use are in Bangladesh and Kolkata in India's mainland. $\mathrm{HCOO}^{-}$and $\mathrm{CH}_{3} \mathrm{COO}^{-}$are reactive organic species, and so long-range transport of them to the study area would end up forming further oxidized forms like $\mathrm{CO}$.

Biomass burning is prevalent in the Brahmaputra Valley region where this study has been undertaken. Agricultural residue burning, forest fire and burning for cooking are many forms of biomass burning have been identified by researchers (e.g., Bhuyan et al., 2018), which intensifies during the winter and pre-monsoon seasons. A unique episodic festive biomass burning takes place each year during mid-January and is characteristic of the Brahmaputra Valley (Deka and Hoque, 2014a).

Factor 4: This factor has contributions from $\mathrm{Br}^{-}, \mathrm{DOC}$ and $\mathrm{NH}_{4}^{+}$, and may be attributed to agricultural emissions. Ammonia is a typical species out of agricultural emission (e.g., Kirchmann et al., 1998; Misselbrook et al., 2000; Zhou et al., 2019). Some $\mathrm{Br}^{-}$is also present in the sea salt fraction of the aerosol. However, $\mathrm{Br}^{-}$did not associate strongly with $\mathrm{Na}^{+}$or $\mathrm{Cl}^{-}$. Biomass burning also has been reported to emit $\mathrm{CH}_{3} \mathrm{Br}$ (Manö and Andreae, 1994). However, there is no association of $\mathrm{Br}^{-}$with $\mathrm{K}^{+}$. Instead, $\mathrm{Br}^{-}$associated with DOC and ammonia. Agriculture is ascribed to be the major contributor of ammonia into the atmosphere. $\mathrm{Br}^{-}$correlating with $\mathrm{NH}_{4}{ }^{+}$would suggest that this group of species represent agricultural emissions. $\mathrm{Br}^{-}$was not present in detectable amounts in all samples and during all seasons, and therefore, the source of $\mathrm{Br}^{-}$has to do with some seasonal activity like agriculture. This region is known for its tea cultivation. Tea is plantation agriculture. Pruning and plucking of tender leaves is a usual activity in the tea gardens that are spread over thousands of acres. It is known that foliage damage enhances organic emission (Churkina et al., 2017 and references therein), Thus, it is envisaged that large volumes of organics are emitted by plantations and forests.

$\mathrm{Br}^{-}$is suspected to be of agricultural origin and methyl bromide $\left(\mathrm{CH}_{3} \mathrm{Br}\right)$ is the likely precursor. Wofsy et al. (1975) explained the sources of atmospheric $\mathrm{Br}^{-}$, especially $\mathrm{CH}_{3} \mathrm{Br}$. They described the reactivity of atmospheric $\mathrm{Br}^{-}$and its removal from the atmosphere by wet scavenging. Methyl bromide is a major reservoir of bromine in the atmosphere. Although historically $\mathrm{CH}_{3} \mathrm{Br}$ was used in agriculture as soil fumigant, it is no longer in use in this form in India. There is a strict restriction on the use of $\mathrm{CH}_{3} \mathrm{Br}$ in compliance with the Montreal Protocol. The tea sector of this region was a major user of $\mathrm{CH}_{3} \mathrm{Br}$ in the past and that has been replaced by alternatives over a decade ago. Over the years, the use of $\mathrm{CH}_{3} \mathrm{Br}$ became limited under strict surveillance of the Indian government. Neighboring Sri Lanka also banned this chemical in 2015. However, crops belonging to Brassicaceae family take up bromine from soil as bromide that is then emitted into the atmosphere as $\mathrm{CH}_{3} \mathrm{Br}$ (Gan et al., 1998). There are reported increasing trends in the emission of $\mathrm{CH}_{3} \mathrm{Br}$ from rapeseed (Brassica napus), mustard (Brassica rapa), and cabbage (Brassica oleracea) (Mead et al., 2008). There is a considerable land area covered with these crops in the region and in India's mainland. This factor also includes contributions of $\mathrm{Mg}^{2+}$ and $\mathrm{Ca}^{2+} . \mathrm{Mg}$ and $\mathrm{Ca}$ are essential nutrients for plant growth, which are used in the foliar application, especially in fruits and vegetable orchards (e.g., Ram et al., 2000; Yildirim et al., 2009). Foliar application of Ca and $\mathrm{Mg}$ improves growth, yield (Dordas, 2009). Foliar application of $\mathrm{Mg}$ in tea plants is an old practice (e.g., Obatolu, 1999). Large area of the region under tea plantation which resort to application of $\mathrm{Mg}$ in a large volume. The process of foliar application could have released much of particulate $\mathrm{Ca}$ and $\mathrm{Mg}$ that have shown association with other indicator species of agricultural emission.

Factor 5: This factor has contributions from $\mathrm{SO}_{4}{ }^{2-}, \mathrm{NH}_{4}{ }^{+}$, and DOC, which are attributed to secondary sulfate. The precursor of $\mathrm{SO}_{4}{ }^{2-}, \mathrm{SO}_{2}$, is emitted by diesel engine burning high sulfur fuels (e.g., Reddy and Venkataraman, 2002; Moldanová et al., 2009; as well as from coal combustion including coal-fired power plants and brick kilns (e.g., Hopke et al., 2005). As reported by the Indian Ministry of Road Transport and Highways, India currently has two fuel quality standards: one that applies to places that meet Bharat Stage IV (BS IV) such as in major cities, and the other follows BS III. Nearly half of the country now requires $50 \mathrm{ppm}$ sulfur diesel and gasoline. The rest of the country, including the region represented in this study, allows up to $150 \mathrm{ppm}$ sulfur in gasoline and $350 \mathrm{ppm}$ sulfur in diesel fuel. Diesel fuel is also used in varieties of other activities like locomotives, captive power generation, and in agricultural irrigation machines. Internal combustion engines will emit a significant amount of the sulfur as $\mathrm{SO}_{3}$ due to adiabatic cooling in the expansion stroke. Thus, these fuels can contribute sulfur in both the S(IV) and S(VI) forms (Santoso et al., 2008). Therefore, there are multiple sources of sulfur both local and distant. Ammonia is the common neutralizer of $\mathrm{SO}_{4}{ }^{2-}$ as observed in this factor.

Again, VOCs undergo hydroxyl radical initiated oxidation leading to the formation of oxidized secondary organics in the atmosphere. Also, Kotnala et al. (2020) reported secondary formation of ammonia from the primary constituents of traffic emissions. Thus, DOC along with $\mathrm{SO}_{4}{ }^{2-}$ and $\mathrm{NH}_{4}{ }^{+}$ represent secondary aerosol formation in the atmosphere. Given the longer reaction times for the formation of secondary sulfate and secondary organic carbon (SOA), this factor likely represents particles transported into the region.

Factor 6: In this factor, crustal elements are present along with $\mathrm{NO}_{3}{ }^{-}$and $\mathrm{SO}_{4}{ }^{2-}$. Nitrate forms rapidly in the atmosphere and the nitric acid can then interact with the alkaline components of the soil to deposit nitrate into the coarse mode aerosol (Wolff, 1984), There can also be reactions 
between $\mathrm{NO}_{2}$ or $\mathrm{SO}_{2}$ and these alkaline crustal components (Zhao et al., 2018). The resulting ions would be released into the droplet when these particles are washed out of the air as the droplet falls to the ground.

Both factors 1 and 6 have high $\mathrm{Ca}^{2+}$ and $\mathrm{Mg}^{2+}$, but factor 1 has little $\mathrm{NO}_{3}{ }^{-}$or $\mathrm{SO}_{4}{ }^{2-}$ while factor 6 does. Factor 1 explains most of the $\mathrm{Ca}^{2+}$ and $\mathrm{Mg}^{2+}$ meaning it is the main soil factor while Factor 6 has much of the $\mathrm{NO}_{3}{ }^{-}$and $\mathrm{SO}_{4}{ }^{2-}$ with less explained variation for $\mathrm{Ca}^{2+}$ and $\mathrm{Mg}^{2+}$. This result implies that most of the soil is not taking up acidic $\mathrm{NO}_{3}{ }^{-}$and $\mathrm{SO}_{4}{ }^{2-}$, but that process represents a major mechanism for getting $\mathrm{NO}_{3}{ }^{-}$and $\mathrm{SO}_{4}{ }^{2-}$ into the precipitation.

\section{CONCLUSIONS}

Rainwater chemistry of mid-Brahmaputra Valley showed seasonal characteristics and the influence of the sea is explicit during the monsoon. Though the region is not fully industrialized yet compared to other regions of India, the levels of constituents in the rainwater show anthropogenic influence, which might indicate that long-range transport of constituents has implications on the rainwater chemistry of the region. As the region receives airmass back trajectories originating from different regions depending on the seasons, the chemistry of the rainfall varies considerably throughout the year. Nearly $60 \%$ of the rain events were found to be alkaline $(\mathrm{pH}>5.6)$ and $28 \%$ rains showed $\mathrm{pH}$ between 5.0 and 5.5 , while $14 \%$ of the rains showed $\mathrm{pH}$ between 4.5 and 5.0. This shows that crustal dust present in the local atmosphere was not efficiently neutralizing the acidic ions, which could be a sign of depleted levels of basic cations in the soils of the region. The decrease in the level of $\mathrm{pH}$ was observed in the subsequent rainfalls, which made it clear that the early rains scavenged the below-cloud neutralizing cations $\left(\mathrm{Ca}^{2+}\right.$ and $\left.\mathrm{Mg}^{2+}\right)$ of crustal origin, leading to poorly neutralized (acidic) rains. The region being ecologically fragile and a biodiversity hotspot, acidic deposition might have impacts on the land and water quality of the region, which could subsequently impact the flora and fauna. This could have implications on the flora and fauna of the unique ecosystems of the region. The PMF model application provided a reasonable solution to identify the sources (viz. Sea-salt, industrial coal burning, biomass burning, agricultural emission, secondary ions, and crustal dust) of the ions associated with the rains and to apportion their strengths. The sources of the ions were both natural and anthropogenic, and a long-term study may appreciate the dynamic nature of rainwater chemistry of the region vis a vis industrial development and climate change.

\section{ACKNOWLEDGEMENTS}

Authors acknowledge the Ministry of Earth Sciences (MoES), GoI for the grant to Raza R. Hoque (Grant No. MoES/16/16/10-RDEAS), however MoES does not have any role in the experimental designs and interpretation of results of this study. The authors gratefully acknowledge the NOAA Air Resources Laboratory (ARL) for the provision of the HYSPLIT transport and dispersion model and
READY website (http://www.ready.noaa.gov) used in this publication. Authors also like to acknowledge the free availability of software, Meteoinfo and Trajstat, used in this publication.

\section{SUPPLEMENTARY MATERIAL}

Supplementary data associated with this article can be found in the online version at https://doi.org/10.4209/aaqr.2 020.02.0072

\section{REFERENCES}

Akpo, A., Lacaux, C.G., Laoualli, D., Delon, C., Liousse, C., Adon, M., Gardrat, E., Mariscal, A. and Darakpa, C. (2015). Precipitation chemistry and wet deposition in a remote wet savanna site in west Africa: Djougou (Benin). Atmos. Environ. 115: 110-123. https://doi.org/10.1016/j. atmosenv.2015.04.064

Al-Khashman, O.A. (2005). Ionic Composition of Wet Precipitation in the Petra Region, Jordan. Atmos. Res. 78: 1-12. https://doi.org/10.1016/j.atmosres.2005.02.003

Al-Khashman, O.A. (2009). Chemical characteristics of rainwater collected at a western site of Jordan. Atmos. Res. 91: 53-61. https://doi.org/10.1016/j.atmosres. 2008. 05.007

Ando, M., Tadano, M., Asanuma, S., Tamura, K., Matsushima, S., Watanabe, T., Kondo, T., Sakurai, S., Ji, R., Liang, C. and Cao, S. (1998). Health effects of indoor fluoride pollution from coal burning in China. Environ. Health Perspect. 106: 239-244. https://doi.org/10.1289/ ehp.98106239

Ando, M., Tadano, M., Yamamoto, S., Tamura, K., Asanuma, S., Watanabe, T., Kondo, T., Sakurai, S., Ji, R., Liang, C., Chen, X., Hong, Z. and Cao, S. (2001). Health effects of fluoride pollution caused by coal burning. Sci. Total Environ. 271: 107-116. https://doi.org/10.1016/s00 48-9697(00)00836-6

Anttila, P., Paatero, P., Tapper, U. and Jarvinen, O. (1995). Application of positive matrix factorization to source apportionment: results of a study of bulk deposition chemistry in Finland. Atmos. Environ. 29: 1705-1718.

Balasubramanian, R., Victor, T. and Chun, N. (2001). Chemical and statistical analysis of precipitation in Singapore. Water Air Soil Pollut. 130: 451-456. https://doi.org/10.1023/A:1013801805621

Bhuyan, P., Barman, N., Begum, S., Gogoi, D., Borah, S., Kumar, M., Sarma, K.P. and Hoque, R.R. (2016). Spatial and seasonal variations of water soluble ions in $\mathrm{PM}_{10}$ of mid-Brahmaputra plain of Assam valley. Asian J. Water Environ. Pollut. 13: 69-81. https://doi.org/10.3233/ajw160018

Bhuyan, P., Barman, N., Bora, J., Daimari, R., Deka, P. and Hoque, R.R. (2016a). Attribution of aerosol bound water soluble ions and carbon, and their relationship with AOD over the Brahmaputra valley. Atmos. Environ. 142: 194209. https://doi.org/10.1016/j.atmosenv.2016.07.045

Bhuyan, P., Deka, P., Prakash A., Balachandran S. and Hoque, R.R. (2018). Chemical characterization and source 
apportionment of aerosol over mid Brahmaputra Valley, India. Environ. Pollut. 234: 997-1010. https://doi.org/10. 1016/j.envpol.2017.12.009

Bouwman, A.F., Lee, D.S., Asman, W. a. H., Dentener, F.J., Hoek, K.W.V.D. and Olivier, J.G.J. (1997). A global high-resolution emission inventory for ammonia. Global Biogeochem. Cycles 11:561-587. https://doi.org/10.1029/ 97GB02266

Budhavant, K.B., Rao, P.S.P., Safai, P.D. and Ali, K. (2009). Chemistry of monsoon and postmonsoon rains at a high altitude Location, Sinhagad, India. Aerosol Air Qual. Res. 9: 65-79. https://doi.org/10.4209/aaqr.2008.07.0033

Budhavant, K.B., Rao, P.S.P., Safai, P.D. and Ali, K. (2011). Influence of local sources on rainwater chemistry over Pune region, India. Atmos. Res. 100: 121-131. https://doi.org/10.1016/j.atmosres.2011.01.004

Campos, M.L.A.M., Nogueira, R.F.P., Dametto, P.R., Francisco, J.G. and Coelho, C.H. (2007). Dissolved organic carbon in rainwater: glassware decontamination and sample preservation and volatile organic carbon. Atmos. Environ. 39: 8924-8931. https://doi.org/10.1016/ j.atmosenv.2007.08.017

Cao, Yu Z., Wang, S., Zhang, G., Luo, J. and Lu, S. (2009). Chemical characteristics of wet precipitation at an urban site of Guangzhou, South China. Atmos. Res. 94: 462469. https://doi.org/10.1016/j.atmosres.2009.07.004

Chaliyakunnel, S., Millet, D.B., Wells, K.C., Cady-Pereira, K.E. and Shephard, M.W. (2016). A large underestimate of formic acid from tropical fires: Constraints from spaceborne measurements. Environ. Sci. Technol 50: 56315640. https://doi.org/10.1021/acs.est.5b06385

Charlson, R.J. and Rodhe, H. (1982). Factors controlling the acidity of natural rainwater. Nature 295: 683-685. https://doi.org/10.1038/295683a0

Chate, D.M., Murugavel, P., Ali, K., Tiwari, S. and Beig, G. (2011). Below-cloud rain scavenging of atmospheric aerosols for aerosol deposition models. Atmos. Res. 99: 528-536. https://doi.org/10.1016/j.atmosres.2010.12.010

Churkina, G., Kuik, F., Bonn, B., Lauer, A., Grote, R., Karolina Tomiak, K. and Butler, T.M. (2017). Effect of VOC emissions from vegetation on air quality in Berlin during a heatwave. Environ. Sci. Technol. 51: 6120-6130. https://doi.org/10.1021/acs.est.6b06514

Crutzen, P.J. and Andreae, M.O. (1990). Biomass burning in the tropics: Impact on atmospheric chemistry and biogeochemical cycles. Science 250: 1669-1678. https://doi.org/10.1126/science.250.4988.1669

Das, R., Das, S.N. and Misra, V.N. (2005). Chemical composition of rainwater and dustfall at Bhubaneswar in the east coast of India. Atmos. Environ. 39: 5908-5916. https://doi.org/10.1016/j.atmosenv.2005.06.030

Das, R., Granat, L., Leck, C., Praveen, P.S. and Rodhe, H. (2011). Chemical composition of rainwater at maldives climate observatory at hanimaadhoo (MCOH). Atmos. Chem. Phys. 11: 3743-3755. https://doi.org/10.5194/acp11-3743-2011

Deka, P. and Hoque, R.R. (2014a). Incremental effect of festive biomass burning on wintertime $\mathrm{PM}_{10}$ in Brahmaputra valley of Northeast India. Atmos. Res. 143:
380-391. https://doi.org/10.1016/j.atmosres.2014.03.003

Deka, P. and Hoque, R.R. (2014b). Diwali Fireworks: early signs of impact on $\mathrm{PM}_{10}$ properties of rural Brahmaputra valley. Aerosol Air Qual. Res. 14: 1752-1762. https://doi.org/10.4209/aaqr.2013.09.0287

Deka P. and Hoque, R.R. (2015). Chemical characterization of biomass fuel smoke particles of rural kitchens of South Asia. Atmos. Environ. 108: 125-132. https://doi.org/10.1 016/j.atmosenv.2015.02.076

Dordas, C. (2009). Foliar application of calcium and magnesium improves growth, yield, and essential oil yield of oregano (Origanum vulgare ssp. hirtum). Ind. Crops Prod. 29: 599-608. https://doi.org/10.1016/j.indcr op.2008.11.004

Eriksson, E. (1952). Composition of atmospheric precipitation. Tellus 4: 280-303. https://doi.org/10.1111/j.2153-3490.1 952.tb01014.x

Galloway, J.N. (1995). Acid deposition: perspectives in time and space. Water Air Soil Pollut. 85: 15-24. https://doi.org/10.1007/BF00483685

Galloway, J.N., Thornton, J.D., Norton, S.A., Volchok, H.L. and McLean, R.A.N. (1982). Trace metals in atmospheric deposition: A review and assessment. Atmos. Environ. 16: 1677-1700. https://doi.org/10.1016/0004-6981(82)90262-1

Gan, J., Yates, S.R., Ohr, H.D. and Sims, J.J. (1998). Production of methyl bromide by terrestrial higher plants. Geophys. Res. Lett. 25: 3595-3598. https://doi.org/10.10 29/98g152697

Ge, B.Z., Wang, Z. F., Xu, X.B., Tang, J., He, Y.J., Uno, I. and Ohara, T. (2011). Impact of the East Asian summer monsoon on long-term variations in the acidity of summer precipitation in Central China. Atmos. Chem. Phys. 11: 1671-1684. https://doi.org/10.5194/acp-11-1671-2011

Granat, L. (1972). On the relation between $\mathrm{pH}$ and the chemical composition of atmospheric precipitation. Tellus 24: 550-560. https://doi.org/10.1111/j.2153-3490.1972.t b01581.x

Granat, L., Das, S.N., Tharkur, R.S. and Rodhe, H. (2001). Atmospheric deposition in a area in India-net and potential acidity. Water Air Soil Pollut. 130: 469-474. https://doi.org/10.1023/A:1013810007438

Guttikunda, S.K., Begum, B.A. and Wadud, Z. (2013). Particulate pollution from brick kiln clusters in the Greater Dhaka region, Bangladesh. Air Qual. Atmos. Health 6: 357-365. https://doi.org/10.1007/s11869-0120187-2

Handa, B.K. (1969). Chemical composition of monsoon rains over Calcutta. Part I. Tellus 21: 95-100. https://doi.org/10.1111/j.2153-3490.1969.tb00421.x

Hopke, P.K., Zhou, L. and Poirot, R. (2005). Reconciling trajectory ensemble receptor model results with emissions. Environ. Sci. Technol. 39: 7980-7983. https://doi.org/10. 1021/es049816g

Jala, S. and Goyal, D. (2006). Fly ash as a soil ameliorant for improving crop production - A review. Bioresour. Technol. 97: 1136-1147. https://doi.org/10.1016/j.biortec h.2004.09.004

Juntto, S. and Paatero, P. (1994). Analysis of daily precipitation data by positive matrix factorization. 
Environmetrics 5: 127-144. https://doi.org/10.1002/env. 3170050204

Keene, W.C., Galloway, J.N. and Holden, J.D., Jr. (1983). Measurement of weak organic acidity in precipitation from remote areas of the world. J. Geophys. Res. 88: 5122-5130. https://doi.org/10.1029/jc088ic09p05122

Khemani, L.T., Momin, G.A., Naik, M.S., Prakash Rao, P.S., Kumar, R. and Ramanamurthy, Bh.V. (1985). Impact of alkaline particulates on $\mathrm{pH}$ of rainwater in India. Water Air Soil Pollut. 24: 365-376. https://doi.org/10.1007/BF 00283789

Kieber, R.J., Peake, B., Willey, J.D. and Avery, G.B. (2002). Dissolved organic carbon and organic acids in coastal New Zealand rainwater. Atmos. Environ. 36: 3557-3563. https://doi.org/10.1016/s1352-2310(02)00273-x

Kirchmann, H., Esala, M., Morken, J., Ferm, M., Bussink, W., Gustavsson, J. and Jakobsson, C. (1998). Ammonia emissions from agriculture. Nutr. Cycling Agroecosyst. 51: 1-3. https://doi.org/10.1023/A:1009738825468

Kotnala, G., Sharma, S.K. and Mandal, T.K. (2020). Influence of vehicular emissions $\left(\mathrm{NO}, \mathrm{NO}_{2}, \mathrm{CO}\right.$ and NMHCs) on the mixing ratio of atmospheric ammonia $\left(\mathrm{NH}_{3}\right)$ in Delhi, India. Arch. Environ. Contam. Toxicol. 78: 79-85. https://doi.org/10.1007/s00244-019-00689-8

Kulshrestha, M.J., Singh, R., Duarah, R. and Rao, P.G. (2014). Influence of crustal aerosols on wet deposition at a rural site of North-East India. Int. J. Environ. Stud. 71: 510-525. https://doi.org/10.1080/00207233.2014.942151

Kulshrestha, M.J., Sekar, R., Krishna, D., Hazarika, A.K., Dey, N.C. and Rao, P.G. (2005a). Deposition fluxes of chemical components of fog water at a rural site in north east India. Tellus B 57: 436-439. https://doi.org/10.3402/ tellusb.v57i5.16566

Kulshrestha, U.C., Kulshrestha, M.J., Sekar, R., Sastry, G.S.R. and Vairamani, M. (2003). Chemical characteristics of rainwater at an urban site of south Central India. Atmos. Environ. 37: 3019-3026. https://doi.org/10.1016/s13522310(03)00266-8

Kulshrestha, U.C., Granat, L., Engardt, M. and Rodhe, H. (2005b). Review of precipitation monitoring studies in India - a search for regional patterns. Atmos. Environ. 39: 7403-7419. https://doi.org/10.1016/j.atmosenv.2005.08.035

Kumar, R., Rani, A., Singh, S.P., Kumari, K.M. and Srivastava, S.S. (2002). A long term study on chemical composition of rainwater at Dayalbagh, a suburban site of semiarid region. J. Atmos. Chem. 41: 265-279. https://doi.org/10.1023/A:1014955715633

Kumar, P.P., Broekhuizen, K. and Abbatt, J.P.D. (2003). Organic acids as cloud condensation nuclei: Laboratory studies of highly soluble and insoluble species. Atmos. Chem. Phys. 3:509-520. https://doi.org/10.5194/acp-3509-2003

Lacaux, C.G., Laouali, D., Descroix, L., Gobron, N. and Liousse, C. (2009). Long term precipitation chemistry and wet deposition in a remote dry savanna site in Africa (Niger). Atmos. Chem. Phys. 9: 1579-1595. https://doi.org/ 10.5194/acp-9-1579-2009

Li, X., Yang, K., Han, J., Ying, Q. and Hopke, P.K. (2019). Sources of humic-like substances (HULIS) in $\mathrm{PM}_{2.5}$ in
Beijing: Receptor modeling approach. Sci. Total Environ. 671: 765-775. https://doi.org/10.1016/j.scitotenv.2019.0 3.333

Liken, G.N., Johnson, N.M., Galloway, J.N., Bormann, F.H., Murphy, T.J., Schaug, J., Semb, A., Huebert, B.J., Wright, R.F., Henriksen, A., Frohliger, J.O. and Kane, R. (1976). Acid precipitation: Strong and weak acids. Science 194: 643-647. https://doi.org/10.1126/science.194.4265. 646-b

Manö, S. and Andreae, M.O. (1994). Emission of methyl bromide from biomass burning. Science 263: 1255-1257. https://doi.org/10.1126/science.263.5151.1255

Masiol, M., Hopke, P.K., Felton, H.D., Frank, B.P., Rattigan, O.V., Wurth, M.J. and LaDuke, G.H. (2017). Source apportionment of $\mathrm{PM}_{2.5}$ chemically speciated mass and particle number concentrations in New York City. Atmos. Environ. 148: 215-229. https://doi.org/10.10 16/j.atmosenv.2016.10.044

Mead, M.I., White, I.R., Nickless, G., Wang, K. and Shallcross, D.E. (2008). An estimation of the global emission of methyl bromide from rapeseed (Brassica napus) from 1961 to 2003. Atmos. Environ. 42: 337-345. https://doi.org/10.1016/j.atmosenv.2007.09.020

Mimura, A.M.S., Almeida, J.M., Vaz, M.A.L., de, Ferreira, C.C.M. and Silva, J.C.J. (2016). Chemical composition monitoring of tropical rainwater during an atypical dry year. Atmos. Res. 169: 391-399. https://doi.org/10.1016/ j.atmosres.2015.11.001

Misselbrook, T.H., Van Der Weerden, T.J., Pain, B.F., Jarvis, S.C., Chambers, B.J., Smith, K.A., Phillips, V.R., and Demmers, T.G.M. (2000). Ammonia emission factors for UK agriculture. Atmos. Environ. 34: 871-880. https://doi.org/10.1016/S1352-2310(99)00350-7

Moldanová, J., Fridell, E., Popovicheva, O., Demirdjian, B., Tishkova, V., Faccinetto, A. and Focsa, C. (2009). Characterisation of particulate matter and gaseous emissions from a large ship diesel engine. Atmos. Environ. 43: 2632-2641. https://doi.org/10.1016/j.atmosenv.2009.02. 008

Momin, G.A., Ali, K., Rao, P.S.P., Safai, P.D., Chate, D.M., Praveen, P.S., Rodhe, H. andGranat, L. (2005). Study of chemical composition of rainwater at an urban (Pune) and a rural (Sinhagad) location in India. J. Geophys. Res. 110: D08302. https://doi.org/10.1029/2004jd004789

Mouli, P.C., Venkata, M.S. and Jayarama, R.S. (2005). Rainwater chemistry at a regional representative urban site: Influence of terrestrial sources on ionic composition. Atmos. Environ. 39: 999-1008. https://doi.org/10.1016/j. atmosenv.2004.10.036

Niu, H., He, Y., Lu, X.X., Shen, J., Du, J., Zhang, T., Pu, T., Xin, H. and Chang, L. (2014). Chemical Composition of Chemical composition of rainwater in the Yulong Snow Mountain region, Southwestern China. Atmos. Res. 144: 195-206. https://doi.org/10.1016/j.atmosres.2014.03.010

Norman, M., Das, A.N., Pillai, A.G., Granat, L. and Rodhe, H. (2001). Influence of air masstrajectories on the chemical composition of precipitation in India. Atmos. Environ. 35: 4223-4235. https://doi.org/10.1016/s1352-2310(01)0025 $1-5$ 
Obatolu, C.R. (1999). Correction of magnesium deficiency in tea plants through foliar applications. Commun. Soil Sci. Plant Anal. 30: 1649-1655. https://doi.org/10.1080/0 0103629909370317

Paatero, P., Eberly, S., Brown, S.G. and Norris, G.A. (2014). Methods for estimating uncertainty in factor analytic solutions. Atmos. Meas. Tech. 7: 781-797. https://doi.org/ 10.5194/amt-7-781-2014

Parashar, D.C., Granat, L., Kulshreshta, U.C., Pillai, A.G., Naik, M.S., Momin, G.A., Rao, P.S.P., Safai, P.D., Khemani, L.T., Naqvi, S.W.A., Narvekar, P.V., Thapa, K.B. and Rodhe, H. (1996). Chemical composition of precipitation in India and Nepal: a preliminary report on an Indo-Swedish project on atmospheric chemistry. Department of Meteorology; Stockholm University, Stockholm, Sweden.

Parashar, D.C., Kulshrestha, U.C. and Jain, M. (2001). Precipitation and aerosol studies in India. Environ. Monit. Assess. 66: 47-61. https://doi.org/10.1023/A:102642401 3890

Pathak, B., Bhuyan, P.D., Gogoi, M. and Bhuyan, K. (2012). Seasonal heterogeneity in aerosol types over DibrugarhNorth-Eastern India. Atmos. Environ. 47: 307-315. https://doi.org/10.1016/j.atmosenv.2011.10.061

Ram, R.A. and Bose, T.K. (2000). Effect of foliar application of magnesium and micro-nutrients on growth, yield and fruit quality of mandarin orange (Citrus reticulata Blanco). Indian J. Hortic. 57: 215-220.

Rao, P.S.P., Khemani, L.T., Momin, G.A., Safai, P.D. and Pillai, A.G. (1992). Measurements of wet and dry deposition at urban location in India. Atmos. Environ. 26: 73-78. https://doi.org/10.1016/0957-1272(92)90038-t

Rao, P.S.P., Tiwari, S., Matwale, J.L., Pervez, S., Tunved, P., Safai, P.D., Srivastava, A.K., Bisht, D.S., Singh, S. and Hopke, P.K. (2016). Sources of chemical species in rainwater during monsoon and nonmonsoonal periods over two mega cities in India and dominant source region of secondary aerosols. Atmos. Environ. 146: 90-99. https://doi.org/10.1016/j.atmosenv.2016.06.069

Rastogi, N. and Sarin, M.M. (2005). Chemical characteristics of individual rain events from a semi arid region in India: Three year study. Atmos. Environ. 39: 3313-3323. https://doi.org/10.1016/j.atmosenv.2005.01.053

Rastogi, N. and Sarin, M.M. (2007). Chemistry of precipitation Events and inter-relationship with ambient aerosols over a semi-arid region in western India. $J$. Atmos. Chem. 56: 149-163. https://doi.org/10.1007/s108 74-006-9047-5

Reddy, M.S. and Venkataraman, C. (2002). Inventory of aerosol and sulphur dioxide emissions from India: IFossil fuel combustion. Atmos. Environ. 36: 677-697. https://doi.org/10.1016/s1352-2310(01)00463-0

Safai, P.D., Rao, P.S.P., Momin, G.A., Ali, K., Chate, D.M. and Praveen, P.S. (2004). Chemical composition of precipitation during 1984-2002 at Pune, India. Atmos. Environ. 38: 1705-1714. https://doi.org/10.1016/j.atmos env.2003.12.016

Salve, P.R., Gobre, T., Lohkare, H., Krupadam, R.J., Bansiwal, A., Ramteke, D.S. and Wate, S.R. (2011).
Source identification and variation in the chemical composition of rainwater at coastal and industrial areas of India. J. Atmos. Chem. 68: 183-198. https://doi.org/10.10 07/s10874-012-9217-6

Salve, P.R., Maurya, A., Wate, S.R. and Devotta, S. (2008). Chemical Composition of Major Ions in Rainwater. Environ. Contam. Toxicol. 80: 242-246. https://oi.org/ 10.1007/s00128-007-9353-x

Santoso, M., Lestiani, D. D., Mukhtr, R., Hamonangan, E., Syafrul, H., Markwitz, A. and Hopke, P.K. (2011). Preliminary study of the sources of ambient air pollution in Serpong, Indonesia. Atmos. Pollut. Res. 2: 190-196. https://doi.org/10.5094/apr.2011.024

Sarin, M., Kumar, A., Srinivas, B., Sudheer, A.K. and Rastogi, N. (2010). Anthropogenic sulphate aerosols and large $\mathrm{Cl}$-deficit in marine atmospheric boundary layer of tropical Bay of Bengal. J. Atmos. Chem. 66: 1-10. https://doi.org/10.1007/s10874-011-9188-Z

Sillapapiromsuk, S., Chantara, S., Tengjaroenkul, U., Prasitwattanaseree, S. and Prapamontal, T. (2013). Determination of $\mathrm{PM}_{10}$ and its ion composition emitted from BB in the chamber for estimation of open burning emissions. Chemosphere 93: 1912-1919. https://doi.org/ 10.1016/j.chemosphere.2013.06.071

Sunder Raman, R., Hopke, P.K. and Holsen, T.M. (2008). Carbonaceous aerosol at two rural locations in New York State: Characterization and behavior. J. Geophy. Res. 113: DI2202. https://doi.org/10.1029/2007jd009281

Talbot, R., Beecher, K., Harris, R. and Cofer, W. (1988). Atmospheric geochemistry of formic and acetic acids at a mid-latitude temperate site. J. Geophy. Res. 93: 16381652. https://doi.org/10.1029/jd093id02p01638

Tiwari, S., Kulshrestha, U.C. and Padmanabhamurty, B. (2007). Monsoon rain chemistry and source apportionment using receptor modeling in and around National Capital Region (NCR) of Delhi, India. Atmos. Environ. 41: 55955604. https://doi.org/10.1016/j.atmosenv.2007.03.003

Tiwari, S., Hopke, P.K., Thimmaiah, D., Dumka, U.C., Srivastava, A.K., Bisht, D.S., Rao, P.S.P., Chate, D.M. and Srivastava, M.K. (2015). Nature and sources of ionic species in precipitation across the Indo-Gangetic plains, India. Aerosol Air Qual. Res. 16: 943-957. https://doi.org/ 10.4209/aaqr.2015.06.0423

Vet, R., Artz, R.S. and Carou, S. (2014). A global assessment of precipitation chemistry and deposition of sulphur, nitrogen, sea-slat, base cations, organic acids, acidity and $\mathrm{pH}$ and phosphorus. Atmos. Environ. 93: 1-2. https://doi.org/10.1016/j.atmosenv.2013.11.013

Wang, H. and Han, G.L. (2011). Chemical composition of rainwater and anthropogenic influences in Chengdu, Southwest China. Atmos. Res. 99: 190-196. https://doi.org/10.1016/j.atmosres.2010.10.004

Wang, Y.Q., Zhang, X.Y. and Draxler, R.R. (2009). TrajStat: GIS-based software that uses various trajectory statistical analysis methods to identify potential sources from long-term air pollution measurement data. Environ. Modell. Software 24: 938-939. https://doi.org/10.1016/j. envsoft.2009.01.004

Wang, Y., Hopke, P.K., Rattigan, O.V., Xia, X., Chalupa, 
D.C. and Utell, M.J. (2011). Characterization of residential wood combustion particles using the twowavelength aethalometer. Enviro. Sci. Technol. 45: 73877393. https://doi.org/10.1021/es2013984

Willey, J.D., Kieber, R.J., Eyman, M.S. and Avery, G.B. (2000). Rainwater dissolved organic carbon: concentrations and global flux. Global Biogeochem. Cycles 14: 139-148. https://doi.org/10.1029/1999gb900036

Wofsy, S.C., McElroy, M.B. and Yung, Y.L. (1975). The chemistry of atmospheric bromine. Geophys. Res. Lett. 2: 215-218. https://doi.org/10.1029/GL002i006p00215

Wolff, G.T. (1984). On the nature of nitrate in coarse continental aerosols. Atmos. Environ. 18: 977-981. https://doi.org/10.1016/0004-6981(84)90073-8

World Meteorological Organization (WMO) (2004). Manual for the $G A W$ precipitation chemistry programme - Guidelines, data quality objectives and standard operating procedures (GAW Report No. 160; WMO TD No. 1251), 186 pp., World Meteorological Organization, Geneva, Switzerland.

Xiao, J. (2016). Chemical composition and source identification of rainwater constituents at an urban site in
Xi'an. Environ. Earth Sci. 75: 209. https://doi.org/10.100 7/s12665-015-4997-z

Yildirim, E., Karlidag, H. and Turan, M. (2009). Mitigation of salt stress in strawberry by foliar $\mathrm{K}, \mathrm{Ca}$ and $\mathrm{Mg}$ nutrient supply. Plant Soil Environ. 55: 213-221. https://doi.org/1 0.17221/383-PSE

Zeng, Y. and Hopke, P.K. (1989). A study of the sources of acid precipitation in Ontario, Canada. Atmos. Environ. 23: 1499-1509. https://doi.org/10.1016/0004-6981(89)90409-5

Zhao, D., Song, X., Zhu, T., Zhang, Z., Liu, Y. and Shang, J. (2018). Multiphase oxidation of $\mathrm{SO}_{2}$ by $\mathrm{NO}_{2}$ on $\mathrm{CaCO}_{3}$ particles. Atmos. Chem. Phys. 18: 2481-2493. https://doi.org/10.5194/acp-18-2481-2018

Zhou, C., Zhou, H., Holsen, T.M., Hopke, P.K., Edgerton, E.S. and Schwab, J.J. (2019). Ambient ammonia concentrations across New York State. J. Geophys. Res. 124: 8287-8302. https://doi.org/10.1029/2019JD030380

Received for review, March 17, 2020 Revised, September 7, 2020 Accepted, September 10, 2020 